\title{
"NGEDESO": PENGEMBANGAN DESA PARIWISATA BERBASIS EDUKASI SOSIAL BUDAYA YANG TERINTEGRASI SEBAGAI UPAYA PEMBERDAYAAN POTENSI DESA GUNUNGRONGGO
}

\author{
Faza Abdurahman Fiddin ${ }^{1}$ dan Anisa Nur Utami ${ }^{2}$ \\ ${ }^{1}$ Agroteknologi, Fakultas Pertanian-Peternakan, Universitas Muhammadiyah Malang \\ ${ }^{2}$ IImu dan Teknologi Pangan, Fakultas Pertanian-Peternakan, Universitas Muhammadiyah Malang
}

\begin{abstract}
Abstrak
Indonesia merupakan negara yang memiliki potensi sumber daya alam, sumber daya manusia, dan budaya yang dapat dikembangkan secara optimal. Meningkatkan kesejahteraan dan ekonomi desa merupakan tantangan yang dihadapi hingga saat ini. Ekonomi yang mengalami peningkatan di sebuah desa dapat menentukan tingkat pembangunan desa. Satu desa yang memiliki potensi untuk dikembangkan, Desa Gunungronggo, adalah salah satu desa yang terletak di kota Malang dengan populasi 1.907 rumah tangga dengan tingkat ekonomi rendah, karena sebagian besar dari mereka bekerja sebagai petani kecil. Selain itu, sebanyak $17 \%$ atau 226 keluarga dari desa Gunungronggo sudah berusia lanjut dan sebagian hidup sendirian dengan pendapatan yang relatif rendah. Sumber keuangan desa berasal dari Alokasi Dana Desa (ADD) yang merupakan dana yang signifikan untuk Village untuk mendukung program desa. Salah satu tujuan dari Alokasi Dana Desa (ADD) adalah pengentasan kemiskinan (Menteri Dalam Negeri Peraturan Nomor 37 Tahun 2007). Namun, seiring dengan jumlah besar Dana Desa, masalah kemiskinan masih sulit untuk memecahkan, oleh karena itu masih perlu pengembangan untuk kesejahteraan desa. Selain itu, desa ini memiliki potensi lain yang dapat dikembangkan seperti tempat wisata dan keragaman makanan lokal. Inovasi yang dapat ditawarkan dalam bentuk "NgeDeso", adalah sebuah aplikasi e-commerce yang mengintegrasikan semua kegiatan yang dilakukan di desa sebagai solusi untuk meningkatkan tingkat perekonomian desa dengan memanfaatkan semua masyarakat desa setempat. Tujuan dari makalah ini adalah 1) Mengoptimalkan potensi orang tua di desa Gunungronggo dan 2) Memperkenalkan pariwisata, budaya dan produk lokal khas Gunungronggo. Metode Penulisan digunakan dalam makalah ini dengan observasi partisipatif, wawancara mendalam, dan review dokumen menambahkan.
\end{abstract}

Kata kunci: NgeDeso, Desa Wisata, Sosial-Budaya Pendidikan, Gunungrongg 


\section{PENDAHULUAN}

Indonesia merupakan negara yang memiliki potensi sumber daya alam yang melimpah, serta sumber daya manusia, dan budaya yang dapat dikembangakan secara optimal. Permasalahan yang dihadapi oleh desa sebagian besar adalah promosi dan pengenalan desa pada masyarakat secara luas sebagai langkah awal untuk meningkatkan perekonomian desa. Perekonomian yang tumbuh di desa menentukan seberapa cepat perkembangan desa tersebut. Pemberdayaan masyarakat memiliki keterkaitan erat dengan suistainable development dimana pemberdayaan masyarakat merupakan prasyarat utama serta dapat diibaratkan sebagai gerbong yang akan membawa masyarakat menuju suatu keberlanjutan ekonomi, sosial dan ekologi yang dinamis. (Mardikanto, 2014:92).

Salah satu desa yang memiliki tingkat perekonomian rendah di Indonesia yaitu desa Gunungronggo. Desa ini terletak di kecamatan Tajinan, kabupaten Malang. Menurut data BPS (2018) desa Gunungronggo memiliki jumlah RW sebanyak 4 dan 31 RT. Luas desa tersebut sebesar 4,18 km2 dengan jumlah penduduk desa sebanyak $1907 \mathrm{KK}$. Penduduk desa Gunungronggo sebagian besar bermata pencaharian sebagai petani kecil tanpa adanya penghasilan tambahan yang diperoleh. Selain itu, 17\% atau $226 \mathrm{KK}$ dari penduduk desa Gunungronggo termasuk lansia dan sebagian besar hidup sendirian dengan penghasilan yang tergolong rendah. Disamping itu, terdapat potensi-potensi yang dapat dikembangakan.

Keanekaragaman produk pangan lokal yang diproduksi oleh masyarakat desa belum dikenal secara luas dikarenakan terdapat kendala di bagian pemasaran dan wadah untuk pemasaran produk. Selain itu, didukung dengan potensi unggulan yang tidak dimiliki oleh desa lainnya yaitu adanya sumber mata air alami bernama Sumber Jenon yang termasuk sumber mata air utama untuk desa. Tetapi potensi-potensi tersebut belum dimanfaatkan secara optimal.

Aktivitas sehari-hari yang dilakukan oleh masyarakat pedesaan tergolong beranekaragam dibandingkan dengan masyarakat yang hidup di perkotaan. Kebudayaan dan aktivitas tersebut dapat digunakan sebagai sarana edukasi berbasis sosial budaya. Jika dilihat berdasarkan daerah tempat tinggal, penduduk pedesaan lebih banyak yang mengikuti kegiatan sosial kemasyarakatan dibanding penduduk perkotaan (88,56\% berbanding 82,94\%). Pada Era Milenial saat ini, sebagian besar mulai melupakan nilainilai sosial dan budaya dalam kehidupan sehari-hari dikarenakan beberapa faktor di atas serta adanya perkembangan teknologi dan globalisasi. Menurut Dyah (2011) menjelaskan bahwa sebanyak 61,1\% pengguna facebook di Indonesia merupakan para remaja usia 14 24 tahun. pengaruh dari perkembangan tersebut dapat mengakibatkan perubahan sosial budaya pada kalangan milenial. Berdasarkan data status desa berdasarkan indeks desa membangun. Desa Gunungronggo termasuk dalam desa berkembang yang memiliki nilai IDM 0,6071, sehingga berpotensi besar dan lebib mudah untuk dikembangkan menuju desa maju dan mandiri. 
Maka dari itu, diperlukan suatu pengembangan guna meningkatkan perekonomian di Desa Gunungronggo. Inovasi yang ditawarkan berupa program yang membantu desa untuk memaksimalkan seluruh potensi desa dengan tujuan mengintegrasikan keseluruhan aspek usaha yang dikemas dalam suatu aplikasi bernama NgeDeso. Program ini diharapkan dapat membantu memperkenalkan desa pada masyarakat secara luas guna memaksimalkan potensi desa itu sendiri.

\section{TINJAUAN PUSTAKA}

\section{Gambaran Umum Desa Gunungronggo}

Gunungronggo adalah sebuah desa di wilayah Kecamatan Tajinan, Kabupaten Malang, Provinsi Jawa Timur. Nama Gunungronggo terdiri dari dua kata yaitu "Gunung" dan "Ronggo" yang artinya mengayomi. Desa ini terkenal akan pemandangan yang indah, dan memiliki sebuah sumber mata air yang terkenal akan keindahannya, yaitu sumber jenon. Menurut data BPS (2018) desa Gunungronggo memiliki jumlah RW sebanyak 4 dan RT sebanyak 31. Luas desa sebesar $4,18 \mathrm{~km}^{2}$ dengan jumlah penduduk total sebanyak $1907 \mathrm{KK}$.

Indeks Desa Membangun disusun dengan menggunakan data Podes tahun 2015 yang terdiri dari 3 (tiga) dimensi yaitu: 1) sosial, 2) ekonomi, dan 3) ekologi/budaya. Ketiga dimensi terdiri dari variabel, dan setiap variable diturunkan menjadi indikator operasional. Jumlah variabel dalam IDM sebanyak 22 variabel dan indikator sebanyak 52 indikator. IDM mengklasifikasi Desa dalam lima (5) status, yakni:

\section{Tabel 1}

\section{Data Status Desa Berdasarkan Indeks Desa Membangun (IDM)}

\begin{tabular}{lll}
\hline No & Tingkatan Desa & Nilai IDM \\
\hline 1 & Desa Sangat Tertinggal & (nilai IDM $<0,491$ ) \\
2 & Desa Tertinggal & (nilai $0,491<\mathrm{IDM}<0,599$ ) \\
3 & Desa Berkembang & (nilai $0,599<\mathrm{IDM}<0,707$ ) \\
4 & Desa Maju & (nilai $0,707<\mathrm{IDM}<0,815)$ \\
5 & Desa Mandiri & (nilai IDM $>0,815$ ) \\
\hline
\end{tabular}

Sumber: Data IDM Jatim, 2019

Berdasarkan data status desa berdasarkan indeks desa membangun. Desa Gunungronggo termasuk dalam desa berkembang yang memiliki nilai IDM 0,6071, sehingga berpotensi besar dan lebib mudah untuk dikembangkan menuju desa maju dan mandiri.

Potensi desa Gunungronggo yaitu terdapat keanekaragaman makanan lokal yang diproduksi oleh masyarakat contohnya kue obong, keripik bawang, keripik gadung, jamu tradisional, dan keripik tempe. Lansia yang memiliki tempat tinggal layak untuk ditempati dengan keadaan yang sederhana, bersih, dan asri dapat digunakan sebagai sarana untuk meningkatkan pendapatan ekonomi desa sebagai tempat penginapan bagi pengunjung. 
Selain itu, potensi unggulan yang dimiliki desa Gunungronggo yaitu terdapat sumber mata air alami yang unik bernama "Sumber Jenon".

\section{Kondisi Perekonomian Desa}

Menurut Mulyanto Susanti (2005), keadaan ekonomi adalah suatu kedudukan yang secara rasional dan menetapkan seseorang pada posisi tertentu dalam masyarakat, pemberian posisi itu disertai pula dengan seperangkat hak dan kewajiban yang harus dimainkan oleh si pembawa status. Masyarakat desa mempunyai aktivitas yang sangat padat dan beragam dimulai dari pagi hari hingga malam. Beragam corak aktivitas yang dilakukan masyarakat desa sehingga aktivitas ini melekat dan menunjukkan sifat masyarakat desa itu sendiri. Oleh karena itu, masyarakat desa juga dikenal sebagai pekerja keras dalam menghasilkan bahan baku yang diperlukan di kota dengan kata lain desa merupakan sumber-sumber ekonomi masyarakat.

Ciri-ciri masyarakat perdesaan yang sangat menonjol ialah memiliki pergaulan yang sangat dekat, saling kenal mengenal diantara penduduk desanya. Menurut ahli yang dikatakan desa ialah yang jumlah penduduknya kurang dari 2500 jiwa, hal ini pula diatur dalam undang-undang desa tahun 2014. Oleh karena itu, masyarakat desa sangat mudah bergaul dan mengenal satu sama lain. Kemudian ciri lain yang melekat ialah cara masyarakat dalam mengurus perekonomiannya, kebanyakan masyarakat kita memiliki mata pencaharian sebagai petani karena wilayah yang sangat agraris yang di pengaruhi oleh alam.

Selain berasal dari masyarakat itu sendiri, sumber keuangan desa berasal dari Alokasi Dana Desa (ADD) merupakan dana yang cukup signifikan bagi Desa untuk menunjang program-program desa. Salah satu tujuan dari Alokasi Dana Desa (ADD) adalah pengentasan kemiskinan (Peraturan Menteri Dalam Negeri Nomor 37 Tahun 2007). Akan tetapi seiring dengan besarnya jumlah Dana Desa, masalah kemiskinan masih sulit untuk diselesaikan (Abidin, 2015).

Masalah kemiskinan merupakan salah satu persoalan mendasar yang menjadi pusat perhatian pemerintah karena tergolong cukup sulit untuk diatasi. Ada suatu saat kemiskinan harus benar terjadi karena adanya suatu kondisi yang memaksa seseorang untuk miskin misalnya krisis ekonomi, gaya hidup dan budaya yang justru mengakibatkan masyarakat Indonesia itu menjadi miskin. Hal tersebut semakin parah dengan banyaknya rumah tangga yang berada di sekitar garis kemiskinan (Astuti, 2012). Maka dari itu diperlukan upaya yang dapat dilakukan untuk mengatasi kemiskinan tersebut. Salah satunya dengan cara memanfaatkan potensi daerah itu sendiri. Berdasarkan data BPS (2017) menyatakan bahwa desa Gunungronggo merupakan satu-satunya desa yang memiliki tempat wisata berupa pemandian yaitu sumber jenon yang dapat digunakan sebagai aset desa untuk meningkatkan perekonomiannya. Masyarakat desa Gunungronggo sebagian besar bekerja sebagai petani kecil, beternak, buruh, maupun pegawai negeri. 


\section{Kondisi Sosial dan Budaya Masyarakat Indonesia}

Menurut data BPS tentang statistika sosial budaya (2018), menjelaskan bahwa Indonesia merupakan negara yang memiliki keanekaragaman budaya. Hal ini mampu menjadi kekuatan tersendiri untuk mendorong terciptanya pembangunan negara. Kondisi sosial budaya masyarakat Indonesia dapat digambarkan secara komprehensif, diantaranya akses informasi baik melalui media cetak maupun media elektronik, interaksi sosial dan partisipasi pada kegiatan kemasyarakatan.

Pemanfaatan internet oleh penduduk berumur 5 tahun ke atas terus menerus mengalami peningkatan baik di perkotaan maupun perdesaan, meskipun persentase di pedesaan jauh lebih kecil dibandingkankan dengan perkotaan. Persentase penduduk berumur 5 tahun ke atas yang pernah mengakses internet selama tiga bulan terakhir juga mengalami peningkatan. Sementara itu, persentase penduduk laki-laki yang mengakses internet lebih besar dibandingkan perempuan (Chasanah,2017).

Tingkat partisipasi masyarakat dalam kegiatan sosial kemasyarakatan merupakan salah satu tolok ukur yang menggambarkan kepedulian masyarakat terhadap lingkungan sosialnya (Tewu,2015). Hasil Susenas MSBP menunjukkan bahwa partisipasi penduduk dalam kegiatan sosial kemasyarakatan di lingkungan sekitar cukup besar, yaitu sebesar 85,43 persen. Jika dilihat berdasarkan daerah tempat tinggal, penduduk pedesaan lebih banyak yang mengikuti kegiatan sosial kemasyarakatan dibanding penduduk perkotaan (88,56 persen berbanding 82,94 persen). Program pengembangan kebudayaan adalah upaya yang dapat dilakukan guna meningkatkan ketahanan budaya dan kontribusi budaya Indonesia dalam peradaban dunia melalui perlindungan, pengembangan, pemanfaatan, dan pembinaan kebudayaan. Unsur kebudayaan yang menjadi sasaran utama pemajuan kebudayaan disebut sebagai Objek Pemajuan Kebudayaan (OPK) yeng terdiri dari tradisi lisan, manuskrip, adat istiadat, ritus, pengetahuan tradisional, teknologi tradisional, seni, bahasa, permainan rakyat.

Terdapat perbedaan penggunaan bahasa dalam pergaulan oleh penduduk berumur 5 tahun ke atas di perkotaan dan di perdesaan. Persentase penduduk di perkotaan lebih banyak yang menggunakan bahasa Indonesia dalam pergaulan (51,39 persen) dibandingkan bahasa daerah (48,40 persen). Penduduk di perkotaan merupakan penduduk majemuk yang datang dari berbagai daerah. Oleh karena itu, dalam pergaulan warga perkotaan lebih banyak menggunakan bahasa Indonesia sebagai bahasa persatuan yang dapat dipahami oleh seluruh penduduk di Indonesia.

\section{METODE PENULISAN}

\section{Teknik Pengumpulan Data Atau Informasi}

Teknik pengumpulan data dalam penelitian kualitatif yang utama adalah observasi partisipatif dan wawancara mendalam, ditambah kajian dokumen, yang bertujuan tidak hanya untuk menggali data, tetapi juga untuk mengungkap makna yang terkandung dalam latar penelitian, dalam melakukan observasi partisipatif, peneliti berperan aktif dalam 
kegiatan di lapang, sehingga peneliti dengan mudah mengamati, karena berbaur dengan yang diteliti. Penggunaan checklist hanya sebagai pelengkap, utamanya adalah membuat catatan lapangan yang terdiri dari catatan deskriptif yang berisi gambaran tempat, orang dan kegiatannya, termasuk pembicaraan dan ekspresinya, serta catatan reflektif yang berisi pendapat, gagasan dan kesimpulan sementara peneliti beserta rencana berikutnya.

\section{Teknik Pengolahan Data}

Proses pengolahan data dilakukan mengkaji dari berbagai literatur dan studi pustaka yang mana dari berbagai jenis sumber pustaka diambil beberapa data yang dibutuhkan untuk mendukung penulisan karya tulis ilmiah. Pengambilan data juga dari beberapa buku, koran dan internet yang sumber-sumbernya terpercaya dan resmi materi yang dibahas juga secara deskriptif melalui pengutipan dan penyaduran, dengan tepat menunjukkan menunjukkan sumber.

\section{Analisis Data}

Analisis dilakukan dengan cara membandingkan intisari-intisari dari sumber bacaan sebagai hasil pengolahan dan penafsiran data, fakta atau informasi. Tahapantahapan yang digunakan ini dibandingkan pula antara data yang tersedia dengan teoriteori yang relevan. Data-data yang diperoleh tersebut dikelola dan dikaitkan intinya sesuai pokok-pokok pembahasan, sehingga bisa mendukung munculnya solusi yang diharapkan sesuai dengan tujuan penelitian.

\section{Penarikan Kesimpulan}

Penarikan kesimpulan dilakukan dengan cara mengambil kesimpulan yang diperoleh setelah mengumpulkan dan menganalisis data lalu membahasnya secara sistematis yang dapat menjawab semua rumusan masalah dan sesuai dengan tujuan penulisan.

\section{Kerangka Berfikir}

\section{Gambar 1}

\section{Kerangka Berfikir}

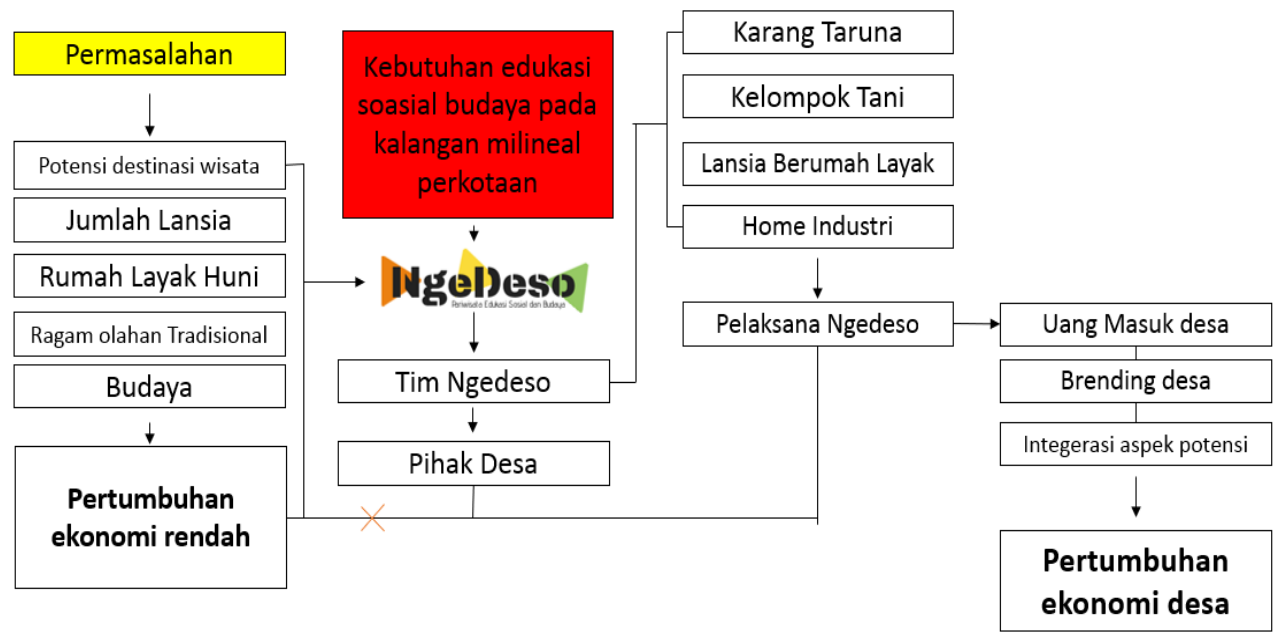


Penulis melakukan observasi desa dan mendapati berbagai permasalahan di desa yaitu potensi destinasi wisata yang belum maksimal dikembangkan dan kesulitan dalam pengenalannya, jumlah lansia yang hidup sendiri atau hanya berdua saja dan ditinggal anak-anak dan cucunya merantau namun memiliki rumah yang cukup layak di tempati dengan masih memiliki bagian bagian tradisional pada rumah serta aktivitas lansia yang masih seperti orang pribumi jaman dulu yang memiliki potensi menjadi tempat edukasi sosial dan budaya, ragam makanan tradisional dari kekayaan alam lokal desa ynag sulit terekspos dan berkembnag karena keterbatasan akses promosi dan orang yang berkunjung ke desa, dan berbagai kegiatan desa (pertanian, peternakan, perikanan, home industri makanan tradisional) yang sesungguhnya dapat dikembangkan sebagai wadah edukasi pendidikan. Dibalik itu terdapat permasalahan di kalangan milenial modern di perkotaan yang semakin menurun tentang pengetahuan sosial dan budaya lokal, hal tersebut efek dari perkembangan teknologi saat ini yang kebanyakan anak" Menghabiskan waktunya untuk berselancar di dunia maya. Kemudian semua aspek potensi desa di kemas dalam satu kegiatan wisata edukasi dengan mengintegrasikan keseluruhan melalui teknologi yang membuat semuanya menjadi lebih efisien. Lapangan penghasilan baru bagai masyarakat desa dan desa memperoleh dana tambahan perputaran ekonomi.

\section{HASIL DAN PEMBAHASAN}

\section{Kondisi Desa Gunungronggo}

Desa Gunungronggo merupakan desa yang memiliki perputaran nilai ekonomi yang kurang optimal. Hal itu disebabkan oleh beberapa faktor salah satunya yaitu perputaran uang hanya berasal dari masyarakat lokal dan tidak adanya uang masuk yang dibawa oleh investor yang dapat berfungsi untuk meningkatkan perputaran uang di desa Gunungronggo. Selain itu, permasalahan yang ada di Gunungronggo yaitu terdapat banyaknya jumlah lansia yang hidup sendiri berkisar 200 orang lansia, dan memiliki tingkat perekonomian rendah lansia tersebut sehari-hari hanya bekerja sebagai buruh tani, kuli, pengembala ternak dan petani kecil dengan perekonomian yang hanya cukup untuk memenuhi kebutuhan makan sehari-hari. Lansia yang tinggal di Gunungronggo memiliki rumah yang tergolong baik dan layak untuk sebuah tempat tinggal dengan keadaan yang sederhana, bersih, dan asri. Letak rumah yang ditinggali oleh lansia sebagian besar tidak jauh dari pusat desa yaitu balai desa Gunungronggo. Setiap lingkungan rumah yang ditinggali oleh lansia memiliki keunikan tersendiri dengan macam-macam aktivitas pekerjaan yang dilakukan oleh masing-masing lansia. Hal tersebut merupakan sebuah potensi yang dapat digunakan sebagai wadah pariwisata berbasis edukasi sosial budaya.

Desa Gunungronggo memiliki keanekaragaman pangan lokal yang diproduksi oleh masyarakat setempat khususnya golongan lansia yaitu terdapat pengolahan kue obong, keripik bawang, keripik gadung, jamu tradisional, keripik tempe dan lontong sayur. Namun, keanekaragaman produk lokal tersebut belum menghasilkan keuntungan yang maksimal sehingga tidak dapat memberikan dampak perekonomian di dalam desa secara 
signifikan. Hal itu dikarenakan adanya kendala dalam proses pemasaran produk, keberlanjutan produksi, serta tidak adanya sentra pengembangan desa yang dapat memfasilitasi pemasaran produk hasil olahan khas Gunungronggo. Potensi unggulan yang dimiliki oleh desa Gunungronggo yaitu terdapat sumber mata air alami yang membentuk sebuah danau dengan nama Sumber Jenon yang memiliki fungsi sebagai pemasok utama kebutuhan air di desa, baik untuk pertanian, kebutuhan sehari-hari maupun untuk air konsumsi. Sumber jenon memiliki keunikan dilihat dari segi keindahan serta sejarah terbentuknya.

\section{Dampak Perubahan Kondisi Sosial Budaya Masyarakat Indonesia}

Perubahan kondisi sosial dan budaya memiliki keterkaitan yang sangat erat. Suatu perubahan sosial akan memberikan pengaruh terhadap perubahan budaya (Atmojo, 2017). Suatu perubahan kebudayaan mencakup semua bagiannya, yaitu kesenian, ilmu pengetahuan, teknologi filsafat, dan pola perilaku dalam kehidupan sehari-hari. Kebudayaan selalu berhubungan dengan kehidupan sosial manusia dalam masyarakat. Keterkaitan kedua hubungan tersebut juga memiliki perbedaan. Perbedaan antara perubahan sosial dan budaya dapat dilihat berdasarkan arahnya, perubahan sosial merupakan perubahan dalam segi struktur dan hubungan sosial, sedangkan perubahan budaya merupakan perubahan dalam segi budaya masyarakat (Baharudin,2006).

Faktor Penghambat perubahan sosial budaya yaitu : (a) Perkembangan ilmu pengetahuan yang terhambat, (b) Sikap masyarakat yang sangat tradisional, (c) Kurangnya hubungan dengan masyarakat lain.(d) Adanya kepentingan-kepentingan yang telah tertanam kuat, (d) Rasa takut dengan adanya kegoyahan pada integrasi kebudayaan, (e) Hubungan yang bersifat idiologis, (f) Adat atau kebiasaan, (g) Prasangka terhadap hal-hal baru dan menilai bahwa hidup ini buruk,susah, dan tidak mungkin diperbaiki.

Pada Era Milenial saat ini, sebagian besar mulai melupakan nilai-nilai sosial dan budaya dalam kehidupan sehari-hari dikarenakan beberapa faktor di atas serta adanya perkembangan teknologi dan globalisasi. Menurut Dyah (2011) menjelaskan bahwa sebanyak 61,1\% pengguna facebook di Indonesia merupakan para remaja usia 14 - 24 tahun. pengaruh dari perkembangan tersebut dapat mengakibatkan perubahan sosial budaya pada kalangan milenial. Adapun dampaknya yaitu: (1) Sikap tidak peduli dengan lingkungan sekitar;(2) Kurangnya sosialisasi dengan lingkungan; (3) Menghamburkan uang untuk kebutuhan internet; (4) Mengganggu Kesehatan; (5) Berkurangnya kegiatan belajar; (6) Kurang perhatian terhadap keluarga; (7) Data pribadi mudah tersebar; (8) Mudah memperoleh konten-konten negatif;(9) Rawan terjadinya perselisihan. Oleh sebab itu, diperlukan suatu pengembangan edukasi berbasis sosial budaya dengan menggunakan teknologi pada era milenial saat ini agar diperoleh dengan mudah oleh generasi milenial tanpa harus mengenyampingkan teknologi.

Dampak positif yang dapat ditimbulkan dari perubahan sosial budaya yaitu perubahan dapat terjadi apabila masyarakat dengan kebudayaan mampu menyesuaikan 
diri dengan gerak perubahan. Keadaan masyarakat yang memiliki kemampuan dalam menyesuaikan diri disebut adjusment, sedangkan bentuk penyesuaian masyarakat dengan gerak perubahan disebut integrasi. Disamping itu, terdapat dampak negatif yang ditimbulkan dari perubahan sosial budaya terjadi apabila masyarakat dengan kebudayaannya tidak mampu menyesuaikan diri dengan gerakan (Dedy, 2001).

Ngedeso

Gambar 2.

Logo NgeDeso

\section{Ngelpeso}

Ngedeso merupakan program yang membantu desa untuk memaksimalkan seluruh potensi desa dengan tujuan mengintegrasikan keseluruhan aspek usaha yang dikemas dalam suatu aplikasi. Guna mempermudahkan seluruh aktivitas usaha sampai ke konsumen, baik dibidang pengenalan dan pengembangan pariwisata, Budaya, Pertanian, Peternakan, Makanan tradisional, dan peningkatan SDM serta SDA lokal desa. Selain itu tujuan akhir dari NgeDeso adalah agar desa dapat menumbuhkan tingkat ekonomi di desa.

\section{Penerapan Konsep Pariwisata Berbasis Edukasi Sosial dan Budaya yang Terintegrasi}

Penerapan pariwisata yang dilakukan dengan mengintegrasikan seluruh aspek potensi desa, adapun di aplikasi NgeDeso terdapat poin-poin yang berkaitan dengan pengembangan desa. Adapun tahapan untuk berwisata di desa yang menjadi member NgeDeso antara lain:

Gambar 3

Tahapan Registrasi
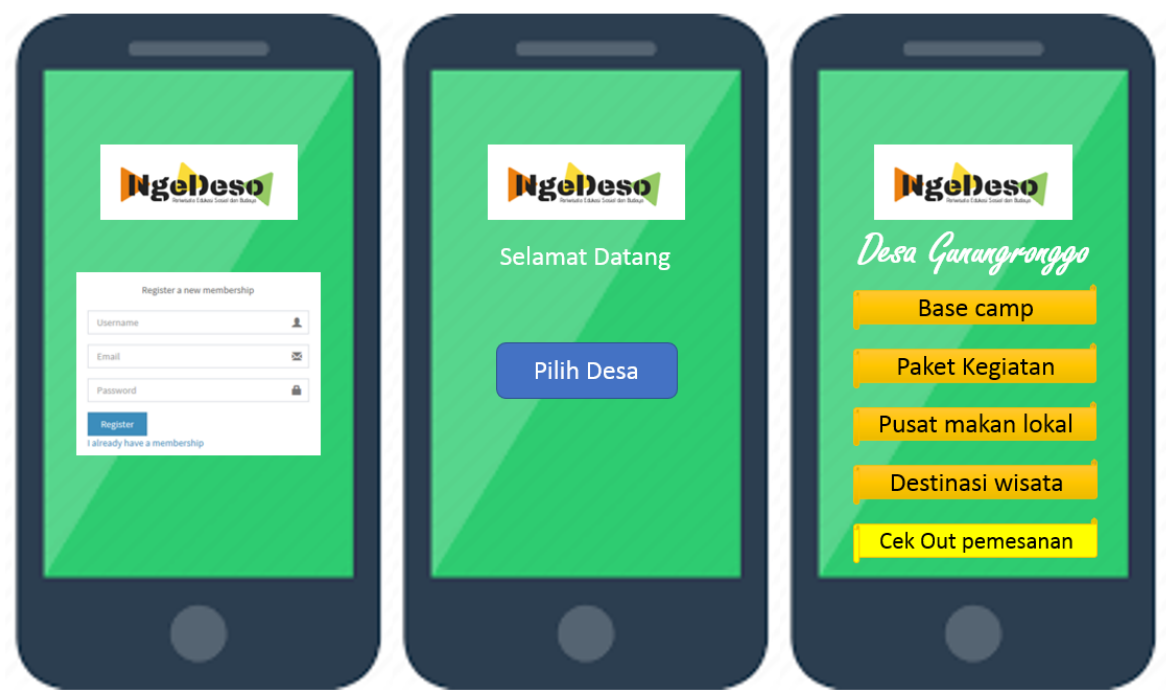
Wisatawan dapat menjadi member dari NgeDeso dan berwisata di desa yang termasuk dalam member NgeDeso, dengan melakukan registrasi kemudian wisatawan dapat memilih desa yang mereka kehendaki. Setelah itu wisatawan dapat memilih poinpoin fasilitas dari NgeDeso yang telah tercantum pada aplikasi.

Gambar 4
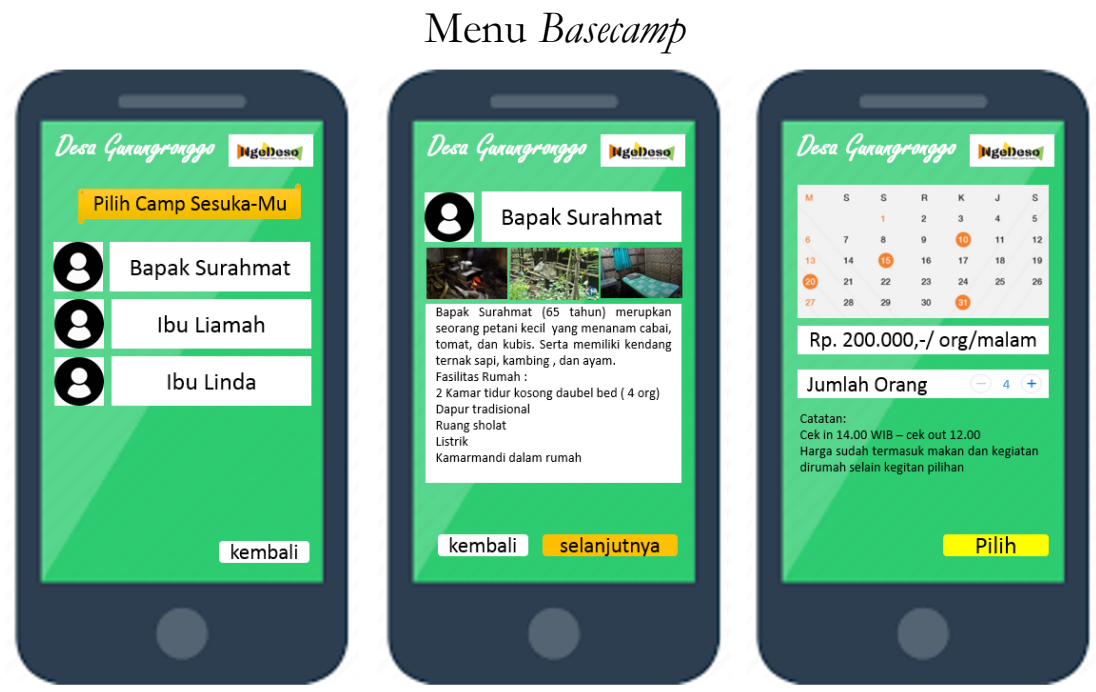

Pada menu Basecamp wisatawan akan menemui pilihan-pilihan camp dari lansia yang memiliki rumah layak huni dan memiliki kegiatan keseharian yang dapat dijadikan edukasi berbasais sosial budaya dengan segala aktivitasnya. Wisatawan bebas memilih dan melihat informasi yang tercantum pada tiap profil camp. dalam camp ini diharapkan wisatawan dapat mempelajari kehidupan sosial dan budaya orang pribumi.

\section{Gambar 5}

Menu paket Kegiatan
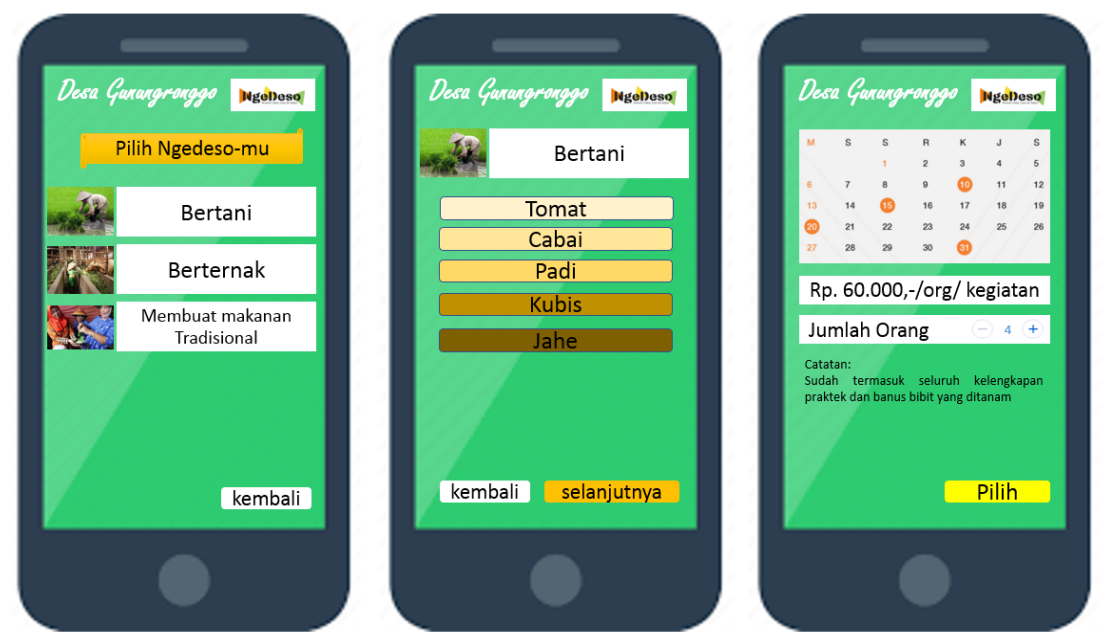

Menu Paket Kegiatan wisatawan dapat menentukan program wisata yang mereka kehendaki selain kegiatan di camp. Wisatawan dapat memilih 3 kategori kegiatan yaitu bertani, beternak, dan memasak makanan tradisional. Kegiatan ini bertujuan untuk memberikan pengalaman pada wisatawan dan mengetahui budaya yang ada di setiap 
member NgeDeso. Hal ini juga untuk dapat digunakan untuk memberdayakan petani dan ibu rumah tangga guna membantu meningkatkan perekonomiannya.

Gambar 6

Menu pusat makanan lokal
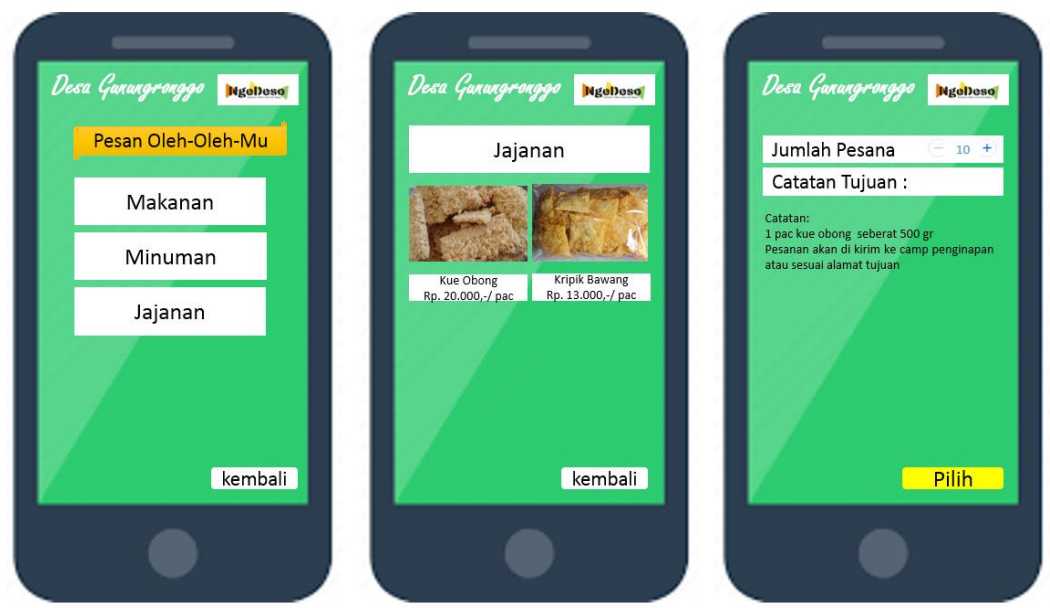

Pusat makanan lokal merupakan menu lokal yang merupakan hasil produksi masyarakat sekitar. Sehingga, tidak dapat membantu dalam hal pemasarannya. Selain itu, permasalahan pada umumnya wisatawan kesulitan untuk menentukan dan memperkirakan jumlah oleh-oleh yang akan dibeli dan kesulitan untuk mencari oleh-oleh ketika berkunjung ke tempat wisata, namun dengan adanya menu ini, sebelum wisatawan berangkat untuk berwisata sudah dapat menentukan oleh-oleh apa saja yang akan dibeli. Oleh-oleh tersebut akan diantar ke camp wisatawan selama berwisata. Pada menu ini tidak hanya wisatawan yang dapat memesan namun semua orang dapat memesan makanan khas desa yang ada pada menu pusat makanan lokal.

\section{Gambar 7}

Menu destinasi wisata
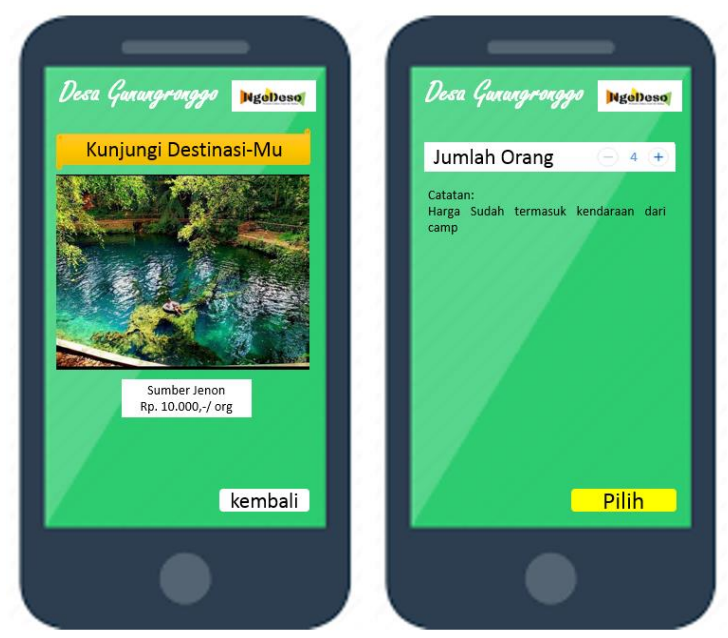

Menu destinasi wisata, membantu mengembangkan dan memperkenalkan kawasan wisata yang unik dan akan dikembangkan oleh pihak desa agar lebih mudah dikenal 
kalangan luas. Serta mempermudah wisatawan untuk mendapatkan akses dan informasi ketika pembelian tiket. Terdapat pengelolaan keuntungan hasil dari penjualan tempat wisata sehingga meminimalisir manipulasi dana.

\section{Gambar 8}

Menu cek out
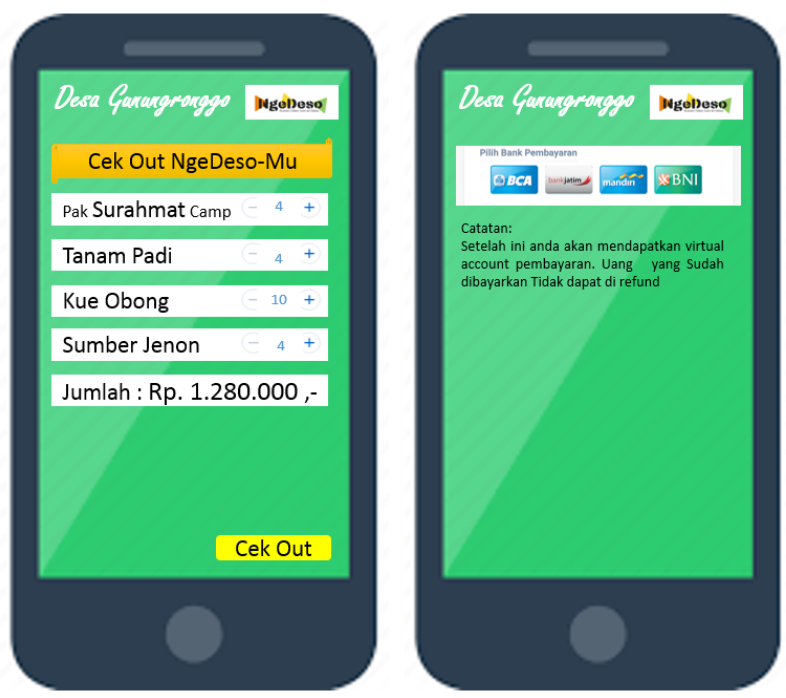

Setelah semua menu dan kebutuhan wisatawan terpenuhi, seluruh pesanan akan otomatis masuk ke menu cek out untuk memberikan informasi total biaya wisata. Kemudian pembayaran dapat dilakukan pada bank yang telah bekerja sama dengan NgeDeso,yang akan menggunakan nomor virtual akun. Kemudian wisatawan dapat membayar dengan berbagai metode yang disediakan oleh bank.

\section{Pihak Yang Terlibat Dan Bentuk Kerjasama}

Gambar 9

Bagan Keterlibatan dan Bentuk Kerjasama

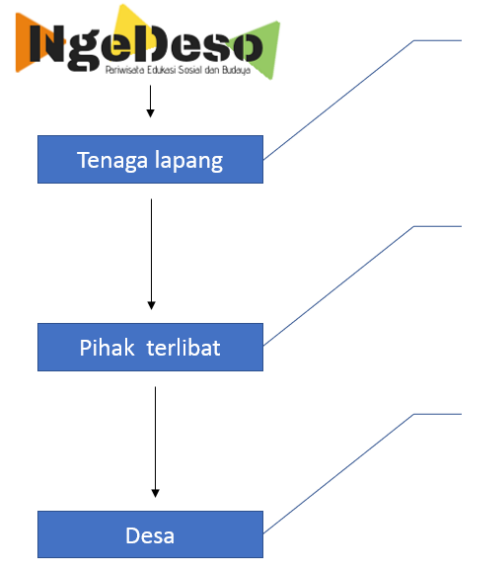

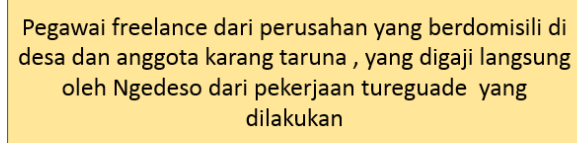

Pihak ini merupakan lansia, pelaku homeindustri, pariwisata, dan penyedia kegiatan dengan perjanjian bagi hasil Ngedesa dan pihak 2 sebesar $30 \%: 70 \%$

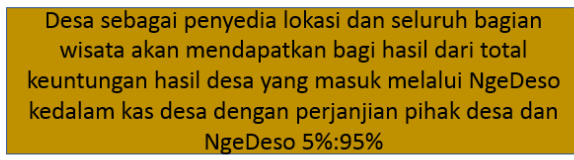

Pihak yang terlibat dalam kegiatan program NgeDeso ini antara lain kepala desa selaku pimpinan desa dan pemberi izin, karang taruna sebagai tour guide, lansia sebagai penyedia fasilitas tempat tinggal atau camp, petani dan ibu rumah tangga desa Gunungronggo sebagai wadah pembelajaran paket kegiatan memasak, bertani, dan 
berternak. kemudian sistem bagi hasil antara Ngedeso dan Pihak terkait sebesar 30\%:70\%. Serta terdapat gaji bagi pelaksana lapang dari karang taruna sebagai tour guide. sedangkan kerjasama untuk pihak desa dengan perjanjian bagi hasil dari NgeDeso dan pihak desa sebesar 95\%: 5\%

\section{Promosi NgeDeso}

Promosi yang dilakukan NgeDeso dengan berbagai upaya dengan bentuk antara lain:

a. Penggunaan Youtuber Influencer Wisata

Era 4.0 saat ini seluruh kegiatan dan informasi dapat diakses menggunakan internet dengan mudah, salah satu media sosial yang menjanjikan dan banyak digemari adalah Youtube dengan banyaknya traveler yang membuat vlog sebagai profesi mereka dengan potensi viewers yang cukup banyak sangat berpotensi digunakan sebagai media promosi dan testimoni sekaligus salah satu konten mereka agar di review.

b. Paid Promote Media Sosial komunitas wisata

Banyaknya kegiatan traveling dan pecinta wisata, yang pada akhirnya memunculkan media sosial komunitas wisata yang pengikutnya merupakan orang yang gemar berwisata merupakan target pasar yang cukup potensi dengan mempromosikan kegiatan edukasi wisata

c. Kerjasama dengan Mitra

Mitra dapat dijadikan sebagai wadah promosi dengan melakukan kerjasama untuk mempromosikan NgeDeso, misalnya mitra pemerintah kabupaten, provinsi, dan kementerian terkait dengan Ngedeso (Kemenristek, Kementerian Desa, dan Kemendikbud) dapat menjadikan wadah promosi ke kalangan luas, selain itu bekerjasama dengan organisasi inovasi yang kerap melakukan seminar dan exhibition dapat menjadi wadah promosi.

d. Media Sosial Official NgeDeso

Milenial saat ini sangat pandai dalam mengakses media sosial hal tersebut menjadi potensi bagi perusahaan e-commerce dalam mempromosikan jasanya secara langsung kepada target pariwisata dengan membuat akun official pada media sosial yang saat ini trend di kalangan masyarakat seperti (Instagram, Website, Youtube, Facebook, dan twitter).

Analisis Kelayakan Usaha Pengembangan Pariwisata berbasis edukasi sosial budaya di Desa Gunungronggo

Analisis ini menggunakan perencanaan permisalan dengan rincian pendapatan dari 1 kelompok dengan 4 orang wisatawan sebagai berikut. Kemudian dengan asumsi jumlah wisatawan dalam 4 tahun target yaitu, tahun ke-1 500 orang, tahun ke-2 750 orang, tahun ke-3 1.000 orang, dan tahun ke-4 1.500 orang. Selain itu dengan investasi pertama sebesar Rp.10.000.000, - dengan bunga total 9\% (Sebanyak 7\% termasuk bunga bank, dan sebanyak 2\% merupakan keuntungan diberikan kepada pihak desa sebagai pajak keuntungan). Penjelasan secara rinci sebagai berikut: 


\section{Analisis Biaya}

\section{Tabel 2}

Analisis Biaya dalam 1 Tahun

\begin{tabular}{|c|c|c|}
\hline Lenis Pengeluaran & Terbilang & Total \\
\hline Gaji penyedia penginapan & Rp.400.000,- & Berdasarkan jumlah \\
\hline Pemateri Kegiatan & Rp. 120.000 ,- & wisatawan tahun \\
\hline Tempat Wisata & Rp. 20.000,- & pertama $\times$ Rp. $640.000=$ \\
\hline Produsen Oleh-Oleh & Rp. 100.000,- & Rp. $80.000 .000,-$ \\
\hline Alokasi transpot mobil & $\begin{array}{l}\text { Rp. } 25.000 \text {,- untuk } 1 \\
\text { kelompok }\end{array}$ & Rp. 3.125 .000 ,- \\
\hline $\begin{array}{l}\text { Gaji Karyawan Inti @2 } \\
\text { orang/bulan }\end{array}$ & Rp. 1.500 .000 ,- & Rp. 36.000 .000 ,- \\
\hline $\begin{array}{l}\text { Gaji Freelance @2 orang / } \\
\text { perdesa }\end{array}$ & $\begin{array}{l}\text { Rp. } 50.000,-/ \text { toure } \\
\text { Dan asumsi dari } 500 \\
\text { oreng terdapat } 125 \\
\text { kelompok }\end{array}$ & Rp. 6.250 .0000 ,- \\
\hline $\begin{array}{l}\text { Administrasi paten di } \\
\text { Notaris }\end{array}$ & $\begin{array}{l}\text { Pembuatan akta PT. } \\
\text { NgeDeso }\end{array}$ & Rp, 4.000.000,- \\
\hline Promosi & Rp. 5.000 .000 & Rp. 5.000 .000 \\
\hline Total & & Rp.116.375..00,- \\
\hline
\end{tabular}

2. Analisis Pendapatan

Tabel 3

Sumber Pendapatan dalam 1 tahun

\begin{tabular}{|l|l|l|}
\hline Sumber Pendapatan & Nominal & \multicolumn{1}{|c|}{ Total } \\
\hline Camp & Rp.800.000,- & Berdasarkan jumlah \\
\hline Wisata & Rp. $40.000,-$ & wisatawan \\
pertama x Rp. 1.280.000 \\
\hline Oleh-Oleh & Rp.200.000,- & $=$ \\
\hline Kegiatan edukasi & Rp.240.000,- & Rp. 160.000.000,- \\
\hline Investasi & & Rp.10.000.000,- \\
\hline Total & Rp.10.000.000,- & Rp. $170.000 .000,-$ \\
\hline
\end{tabular}

3. Analisis Investasi (NPV, IRR, Payback Period)

Tabel 4

Analisis Investasi NPV dan IRR

\begin{tabular}{|c|c|c|c|c|}
\hline Investasi & Cash Flow & & & \\
\hline 0 & -10000000 & & & \\
\hline 1 & 185000000 & & & \\
\hline 2 & 277000000 & & & \\
\hline 3 & 370000000 & Suku Bunga & $9.00 \%$ & \\
\hline 4 & 555000000 & & & \\
\hline Total & 1377000000 & & & \\
\hline NPV & $107175400854.082000 \%$ & & Kesimpulan & LAYAK \\
\hline IRR & $1899 \%$ & & & \\
\hline
\end{tabular}


Tabel 5

Analisis Payback Period

\begin{tabular}{|c|c|c|c|}
\hline Periode & Cash Flow & Cash Flow Kumulatif & Payback Periode (Years) \\
\hline 0 & -10000000 & -10000000 & \\
\hline 1 & 22040000 & 12040000 & 0.453720508 \\
\hline 2 & 29000000 & 41040000 & 0.584827586 \\
\hline 3 & 52200000 & 93240000 & 1.213793103 \\
\hline 4 & 69600000 & 162840000 & 1.660344828 \\
\hline
\end{tabular}

Tabel 6

\section{Panduan NPV}

\begin{tabular}{|c|c|c|}
\hline Apabila & Berarti & Keterangan \\
\hline $\mathrm{NPV}>0$ & $\begin{array}{l}\text { Investasi yang dilakukan memberikan } \\
\text { manfaat bagi perusahaan }\end{array}$ & Proyek bisa dijalankan \\
\hline$N P V<0$ & $\begin{array}{l}\text { Investasi yang dilakukan mengakibatkan } \\
\text { kerugian bagi perusahaan }\end{array}$ & Proyek ditolak \\
\hline$N P V=0$ & $\begin{array}{l}\text { Investasi yang dilakukan tidak } \\
\text { mengakibatkan untung atau kerugian } \\
\text { bagi perusahaan }\end{array}$ & $\begin{array}{l}\text { Jika proyek dilaksanakan atau } \\
\text { tidak dilaksanakan tidak akan } \\
\text { berpengaruh }\end{array}$ \\
\hline
\end{tabular}

Berdasarkan analisa proyek wisata seperti di atas, nilai NPV yang dihasilkan sebesar $107175400854,082000 \%>0$ yang artinya investasi yang dilakukan dapat memberikan manfaat bagi perusahaan dan proyek dapat dijalankan. Selain itu, berdasarkan analisis IRR sebesar $1899 \%>$ pendapatan, dan artinya proyek dapat dilanjutkan. Serta waktu balik modal (payback period) 1,6 tahun pada tahun ke-4. Sehingga berdasarkan perhitungan di atas, program NgeDeso dapat dikembangkan menjadi sebuah usaha baru yang dapat membantu meningkatkan perekonomian suatu desa.

\section{Efisiensi NgeDeso dibandingkan dengan E-commerce Pariwisata yang telah ada}

Efisiensi program NgeDeso dalam mengembangkan potensi desa yang berdampak terhadap peningkatan perekonomian desa dibandingkan dengan aplikasi e-commerce pariwisata yang terkenal di kalangan masyarakat yaitu sebagai berikut:

\section{e-commerce pariwisata yang telah ada:}

1. Tidak terfokus pada pengembangan potensi daerah atau desa yang berdampak terhadap peningkatan perekonomian desa.

2. Kerjasama yang dilakukan sebatas dengan perusahaan pariwisata yang telah menyediakan paket pariwisata dengan destinasi wisata yang telah dikenal masyarakat luas

3. Tidak memiliki menu pilihan oleh-oleh khas daerah tempat wisata

4. Tidak menyediakan edukasi berbasis sosial budaya

5. Tidak ada keuntungan yang langsung masuk ke daerah pariwisata yang bersangkutan 


\section{e-commerce NgeDeso:}

1. Berfokus dalam pengembangan suatu daerah atau desa yang akan berdampak terhadap peningkatan perekonomian suatu desa

2. Memanfaatkan seluruh SDM, SDA lokal dari suatu desa sebagai penyedia fasilitas pariwisata

3. Memiliki menu pilihan oleh-oleh khas daerah tempat wisata yang sehingga dapat mengangkat potensi desa dan produk dikenal oleh masyarakat luas

4. Bentuk pariwisata edukasi berbasis sosial budaya

5. Memiliki program bagi hasil sehingga tempat wisata dapat memperoleh penghasilan dari penggunaan program NgeDeso

\section{Kesimpulan}

Berdasarkan karya ilmiah di atas, dapat disimpulkan bahwa :

1. Program NgeDeso dapat digunakan sebagai upaya guna mengembangkan dan memanfaatkan potensi desa serta meningkatkan perekonomiannya.

2. Berdasarkan perhitungan analisis program penerapan NgeDeso diperoleh nilai NPV yang dihasilkan sebesar 107175400854,082000\% > 0 yang artinya investasi yang dilakukan dapat memberikan manfaat bagi perusahaan dan proyek dapat dijalankan. Selain itu, berdasarkan analisis IRR sebesar $1899 \%>$ pendapatan, dan artinya proyek dapat dilanjutkan. Serta waktu balik modal (payback period) 1,6 tahun pada tahun ke4. Sehingga berdasarkan perhitungan di atas, program NgeDeso dapat dilanjutkan dan dikembangkan menjadi sebuah usaha baru yang dapat membantu meningkatkan perekonomian suatu desa.

\section{DAFTAR PUSTAKA}

Abidin, Muhammad Z. 2015.Tinjauan atas Pelaksanaan Keuangan Desa dalam Mendukung Kebijakan Dana Desa. Jurnal Ekonomi \& Kebijakan Publik. Vol. 6 No.1, hlm 61-76.

Astuti, P. B. 2012. Efektivitas dan Pengaruh PNPM Mandiri Perdesaan, Alokasi Dana Desa, Pendapatan Asli Desa dan Jumlah Penduduk Terhadap Jumlah Keluarga Miskin di Kabupaten Kebumen Tahun 2009-2011. Jurnal Admisnistrasi Publik, 19.

Badan Pusat Stastistik. 2018. Kecamatan Tajinan Dalam Angka. Katalog: 1102001.3507230: No. Publikasi: 35070.1825.

Badan Pusat Stastistik. 2018. Satatistik Sosil Budaya 2018. Katalog BPS: 4501001, ISSN :2086-4574.

Dedy, M., Jalaluddin R. (2001). Komunikasi Antar Budaya. Bandung: Remaja Rosdakarya. Mardikanto T, Soebiato P, 2013, Pemberdayaan Masyarakat. Bandung, Alfabeta

Susanti. 2005. Hubungan Antara Keadaan Sosial Ekonomi Orang Tua Tentang Tingkat Pendidikan Dengan Anak Putus Sekolah. Pelita. Tanjung Karang Barat.

Sutoro Eko, dkk, Desa Membangun Indonesia, (Yogyakarta: Forum Pengembangan Dan Pembaharuan Desa (FPPD) dan ACCESS, 2014), hlm. 12-13. 
Atmojo, M.E., Fridayani, H.D., Kasiwi, A.N dan Pratama, M.A. 2017. Efektivitas dana desa untuk pengembangan potensi ekonomi berbasis partisipasi masyarakat di Desa Bangunjiwo. Sosial Politik Humaniora, 5(1): 126-1

Chasanah, K., Rosyadi, S., dan Kurniasih, D. 2017. Implementasi Kebijakan Dana Desa. IJPA-The Indonesian Journal of Public Administration, 3 (2): 12-31.

Tewu, M.E. 2015. Peranan sumber daya manusia dalam meningkatkan aktivitas Kelompok Tani di Desa Tember. E-journal Acta Diurna, 4(3): 1-9.

Mustanir, A. dan Abadi, P. 2017.Partisipasi Masyarakat Dalam Musyawarah Rencana Pembangunan Di Kelurahan Kanyuara Kecamatan Watang Sidenreng KabupatenSidenreng Rappang. Jurnal Politik Profetik, 5(2): 247-261 